Journal of Animal and Veterinary Advances 10 (13): 1678-1682, 2011

ISSN: $1680-5593$

(C) Medwell Journals, 2011

\title{
Serotyping Dichelobacter nodosus with PCR-SSCP
}

\author{
${ }^{1}$ Tulay Ifakat Cagatay and ${ }^{2}$ Jon Hickford \\ ${ }^{1}$ Department of Basic Sciences, Faculty of Fisheries, Akdeniz University, 07058 Antalya, Turkey \\ ${ }^{2}$ Agriculture and Life Sciences Divisions, Lincoln University, P.O. Box 84 , \\ 7647 Lincoln, New Zealand
}

\begin{abstract}
In this study, we reported rapid approach for identification of D. nodosus serotypes that causes footrot, higly contagious diseases of the ruminants in worldwide with using Polymerase Chain Reaction-Single Strand Conformational Polymorphism (PCR-SSCP) analysis. A total of 500 swab samples from infected hoof lesion were investigated for presence of $D$. nodosus by PCR amplification of fimA gene. PCR-SSCP patterns revealed that each sample contained two or three different $D$. nodosus serotypes. Additionally on the of basis SSCP patterns, 8 different serogroups (A- G and I) were identified from New Zealand samples. These findings were confirmed by cloning and sequences of fim $A$ gene.
\end{abstract}

Key words: Dichelobacter nodosus, fimA gene, PCR, Single Strand Conformational Polymorphism (SSCP), sequencing, sample

\section{INTRODUCTION}

D. nodosus is an anaerobe, fastidious, slow growing and gram negative bacterium (Stewart, 1989). D. nodosus has a number of serogroups based on its fimbrial antigens (Whittington et al., 1997; Moore et al., 2005). The current Australian classification systems classifies $D$. nodosus into at least 10 serogroups (A-I and M) (Claxton et al., 1983; Ghimire et al., 1998). Traditionally, identifiying and characterization of $D$. nodosus serotypes have required sample collection from infected hooves followed by careful and rapid transport of lesion material in specialized media to the laboratory.

Following this, specific plating media are used to grow the D. nodosus (Stewart et al., 1986). This is then followed by streak plating to obtain single colonies and subsequent analysis of both the morphology of these single colonies and antigenic analysis with serological methods which could take 3-4 weeks to verify the presence of D. nodosus (Hindmarsh and Fraser, 1985; Depiazzi et al., 1991; Gradin et al., 1993). Previously, PCR has been used in identifying bacteria based on the amplification of the fimA gene (John et al., 1999; Dhungyel et al., 2002; Myers et al., 2007) and 16S rDNA gene (Zakaria et al., 1998; Wani et al., 2007; Zhou et al., 2010). While this gives a more definitive identification of D. nodosus and down to the level of individual isolates, the approach is still reliant upon the retrieval and culture of live cells, something that is both time-consuming and technically costly. Moreover, the observation that multistrains of $D$. nodosus occur on a single hoof means that multiple plates need to be screened to be sure that all the strains present on a footrot infected hoof are identified. The objective of present investigation is describe a rapid approach that involves the PCR-SSCP-based direct analysis of field samples collected off footrot infected hooves and without the need for live cell retrieval, culturing or classical morphological identification for serotyping $D$. nodosus.

\section{MATERIALS AND METHODS}

Sample collection: Samples were collected from footrot infected hooves using swabs to scrape the axial skin-horn junction of the hoof. The ends of the swabs were cut off into $5 \mathrm{~mL}$ screw-capped Bijou bottles containing Stuart's transport medium (Skerman, 1989) and transferred to the laboratory for DNA extraction. Reference D. nodosus 25549 was obtained from the American Type Culture Collection (ATCC) (Manassas, VA, USA). Cultures of 12 D. nodosus strains from serogroup A-M were obtained from Shearing-Plough Animal Health Ltd. (SPAHL), Upper Hutt, New Zealand.

DNA extraction and PCR amplification: DNA from field swabs and reference cultures were extracted as described by Cagatay and Hickford (2005). The D. nodosus fimA genes was amplified, using of mixture of primers sets (fU1, fU2, rD1-rD3) as described previously by Cagatay and Hickford (2006). Amplicons were visualized by electrophoresis in $1 \%$ agarose (BioWhittaker Molecular Applications, Rockland, ME) gels, using

Corresponding Author: Tulay Ifakat Cagatay, Department of Basic Sciences, Faculty of Fisheries, Akdeniz University, 07058 Antalya, Turkey 
$1 \times$ TBE buffer ( $89 \mathrm{mM}$ Tris-borate, $89 \mathrm{mM}$ boric acid, $2 \mathrm{mM} \mathrm{Na} \mathrm{Na}_{2}$ ETDA) containing $200 \mathrm{ng}$ of ethidium bromide $\mathrm{mL}^{-1}$.

SSCP analysis and sequence analysis: A $2 \mu \mathrm{L}$ of each amplicon was mixed with $7 \mu \mathrm{L}$ of loading dye $(95 \%$ formamide, $10 \mathrm{mM}$ EDTA, $0.025 \%$ bromophenol blue, $0.025 \%$ xylene cyanol) and after denaturation at $95^{\circ} \mathrm{C}$ for $5 \mathrm{~min}$, samples were rapidly cooled on wet ice and then loaded to $16 \times 18 \mathrm{~cm}, 8 \%$ acrylamide: bisacrylamide (49:1; Bio-Rad Laboratories, Inc., Hercules, CA, USA) gels.

lectrophoresis was performed using protean IIxi cells (Bio-Rad) at $220 \mathrm{~V}$ for $16-18 \mathrm{~h}$ at $4^{\circ} \mathrm{C}$ in $0.5 \times \mathrm{TBE}$ buffer and gels were silver-stained (Bassam et al., 1991). Amplicons representative of unique PCR-SSCP patterns were ligated into the Invitrogen ${ }^{\mathrm{TM}}$, One Shot $^{\mathrm{TM}} \mathrm{INV} \alpha \mathrm{F}$ system (Invitrogen, USA). The ligation mixture were used to transform competent $E$. coli cells following the manufacturer's instructions. Fifteen insert positive colonies for each transformation were picked and incubated overnight in Terrific broth (Invitrogen) at $37^{\circ} \mathrm{C}$ in a shaking rotary incubator. Amplicons from these clones and the corresponding genomic DNA were run adjacent to each other on SSCP gels for comparison. Clones where the SSCP pattern matched those of the corresponding genomic $D$. nodosus DNA were selected for DNA sequencing. Sequencing was perform as described previously by Cagatay and Hickford (2006).

\section{RESULTS AND DISCUSSION}

About 500 potential swabs were examined with gram stain and then PCR for presence of $D$. nodosus. DNA from positive samples were typically revealed an amplimer of approximately 440 bp of the fim $A$ gene (Fig. 1a-c). A 112
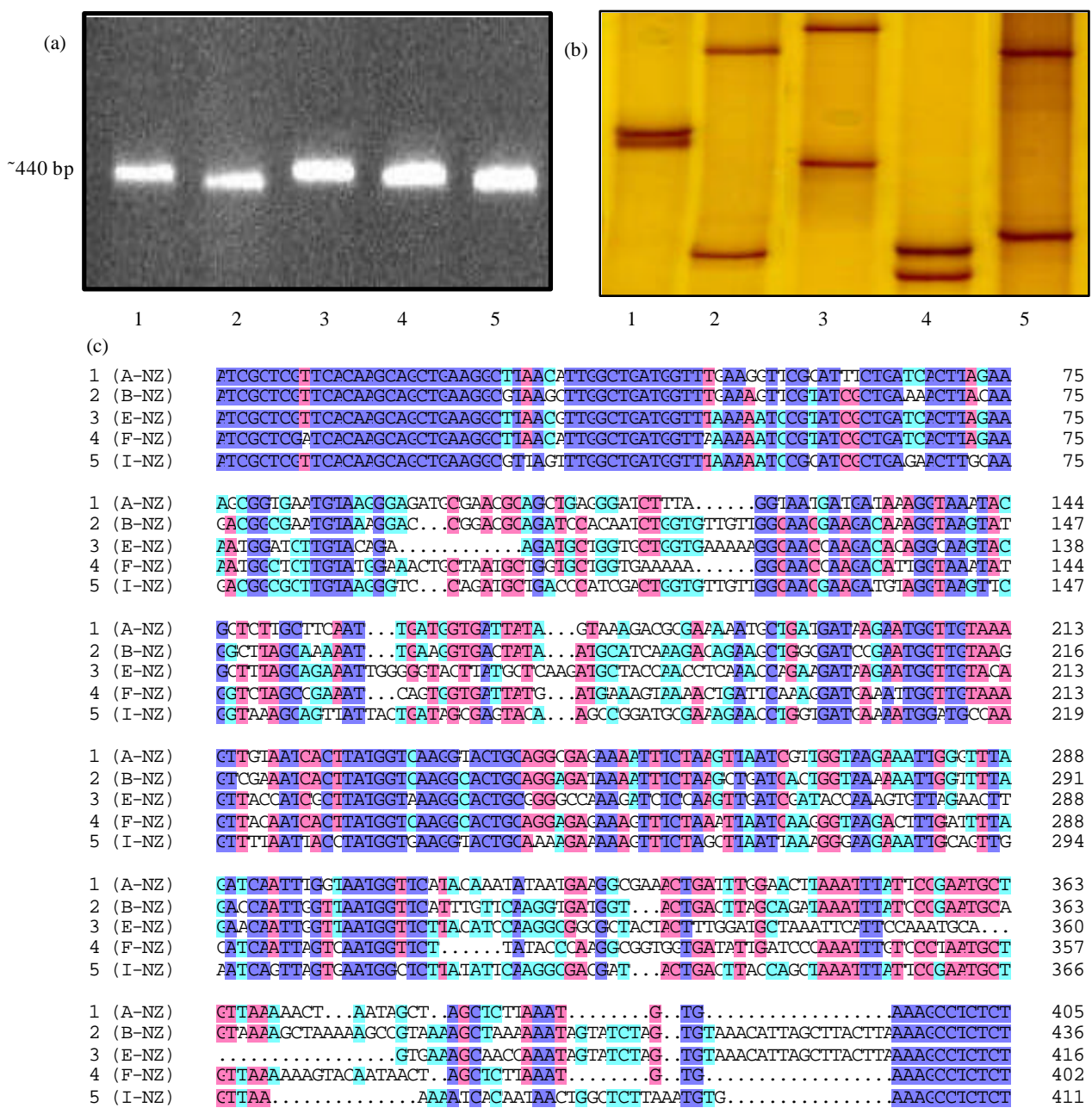

Fig. 1: a) Five different PCR products in agarose revealing minor variation in amplimer length; b) the amplicons show different PCR-SSCP patterns on an $8 \%$ polyacrylamide gel; c) PCR products were cloned and sent for sequencing. Sequences show the variable region of the fimA gene for sample 1-5 
Table 1: Footrot Samples (FS) and serotypes detected

\begin{tabular}{|c|c|c|c|c|c|}
\hline \multirow{2}{*}{$\begin{array}{l}\text { Sample } \\
\text { name }\end{array}$} & \multicolumn{2}{|c|}{$\begin{array}{l}\text { 1st examination } \\
\text { of swab }\end{array}$} & \multirow{2}{*}{$\begin{array}{l}\text { No. of } \\
\text { cloned } \\
\text { amplimers } \\
\text { examined }\end{array}$} & \multirow{2}{*}{$\begin{array}{l}\text { No. of } \\
\text { unique strains } \\
\text { identified by } \\
\text { PCR-SSCP }\end{array}$} & \multirow{2}{*}{$\begin{array}{l}\text { Serotypes } \\
\text { identified } \\
\text { by DNA } \\
\text { sequencing }\end{array}$} \\
\hline & Gram strain & PCR & & & \\
\hline FS-1 &,+- & + & 10 & 4 & $\mathrm{~A}, \mathrm{~F}$ \\
\hline FS-2 &,+- & + & 7 & 2 & $\mathrm{E}, \mathrm{F}$ \\
\hline FS-3 & + & + & 4 & 1 & $\mathrm{E}, \mathrm{F}$ \\
\hline FS-4 & + & + & 5 & 2 & B, I \\
\hline FS-5 &,+- & + & 5 & 1 & I \\
\hline FS-6 & + & + & 10 & 3 & B \\
\hline FS-7 &,+- & + & 6 & 6 & $\mathrm{~B}, \mathrm{C}, \mathrm{G}, \mathrm{M}$ \\
\hline FS-8 &,+- & + & 10 & 5 & $\mathrm{~A}, \mathrm{~B}, \mathrm{E}, \mathrm{F}, \mathrm{I}$ \\
\hline FS-9 & + & + & 5 & 1 & I \\
\hline FS-10 &,+- & + & 5 & 1 & $\mathrm{~B}, \mathrm{~F}$ \\
\hline FS-11 & + & + & 15 & 4 & $\mathrm{~B}, \mathrm{E}$ \\
\hline FS-12 &,+- & + & 5 & 4 & $\mathrm{E}, \mathrm{E}$ \\
\hline FS-13 &,+- & + & 10 & 3 & $\mathrm{C}, \mathrm{M}$ \\
\hline FS-14 &,+- & + & 5 & 2 & $\mathrm{~F}, \mathrm{E}$ \\
\hline FS-15 & + & + & 10 & 7 & $\mathrm{~B}, \mathrm{C}, \mathrm{F}, \mathrm{M}$ \\
\hline
\end{tabular}

DNA amplicons were cloned and screened and 52 of these were chosen following PCR-SSCP (Table 1). The PCRSSCP patterns generated from those samples suggested that they contained at least two or three different $D$. nodosus strains that were different to those previously identified New Zealand strains. The new strains were from serogroups A-I (Fig. 2). These PCR-SSCP pattern differences were investigated in more detail. Five similar size $D$. nodosus amplicons were analyzed confirmed by replicating the PCR amplification (Fig. 1a).

The amplicons producing each of these five PCRSSCP patterns (Fig. 1b) were chosen for subsequent cloning and DNA sequencing and this confirmed that the fimA gene sequences from each of the colonies were different (Fig. 1c). The fim $A$ gene inserted from clone one showed a high degree of sequence homology to the fim $\mathrm{A}$ sequence of serogroup A whereas clones 2-5 showed a high degree of sequence homology with fimA from serogroups B, E, F and I, respectively. Traditionally, the isolation and definitive identification of $D$. nodosus serotypes from footrot microflora is difficult and requires morphological characterisation of both the bacterium and colonies, gram staining and the use of other laboratory tests such as the elastase (Links and Morris, 1996) and gelatin tests (Palmer, 1993).

DNA sequencing can assist this identification but single colonies are needed prior to using this approach. Here, there is reveal how fimA gene specific PCR and SSCP can be used to quickly and easily detect and differentied $D$. nodosus in DNA obtained directly from footrot lesions and without plating or colony isolation. The existence of considerable structural variation in the fimbrial gene of $D$. nodosus is well known (Ghimire et al., 1998; Gurung et al., 2006). The results confirmed that as little as a single nucleotide difference in the fimA sequences of PCR amplimers can be detected by PCR-

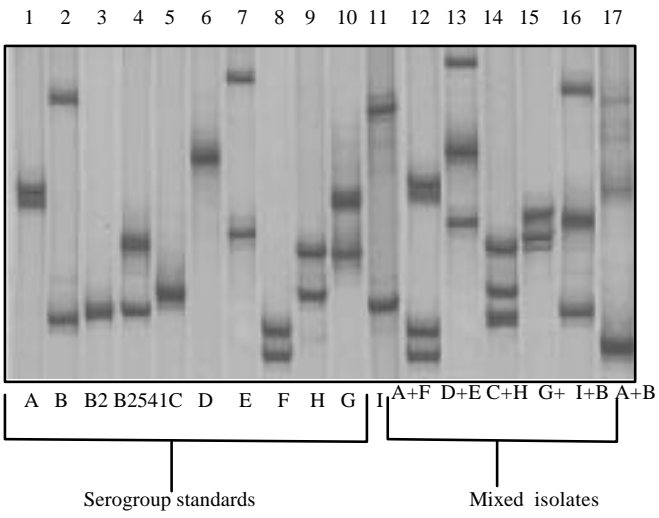

Fig. 2: PCR-SSCP analysis of the fimA gene of D. nodosus. Each line presents one genotype of D. nodosus. Lanes 1-11 are different serotypes from the control strains of $D$. nodosus. Lanes 12-17 represent mixed samples

SSCP. It is therefore, a simple and powerful way to identify, characterize and serotypes new $D$. nodosus with less time consuming methods. On the basis of PCR-SSCP and DNA sequencing, sixteen new $D$. nodosus strains belonging to eight different serogroups were detected in this research. Strains from serogroups $H$ was not detected which contrasts the findings of Kingsley et al. (1986) who reported that serogroup D and $H$ were the 2 nd most common in New Zealand.

Moore et al. (2005) reported that serogroup $\mathrm{H}$ has retained its position of importance in England and Wales over the last 20 years. Thorley and Day (1986) who investigated 58 farms around the UK also identified serogroup $\mathrm{H}$ to be dominant. In contrast this study found that serogroup $\mathrm{E}$ was the most common serogroup in New Zealand and was present in around $30 \%$ of the samples taken from the four New Zealand farms. In the findings, the 2 nd most common serogroup was serogroup $\mathrm{B}$ and the 3rd was serogroup A. These findings are consistent with those of Chetwin et al. (1991) who also reported the finding that serogroup $\mathrm{E}$ occurs in around $20 \%$ of New Zealand flocks. Coincidentally, serogroup E is the most common pathogenic serogroup in Nepal with a sheep industry that originated from imported rams from New Zealand. Serogroup E is reportedly uncommon in Australia (Claxton et al., 1983), the United Kingdom (Kingsley et al., 1986) and the United States of America (Gradin et al., 1993).

Additionally, a single swab confirmed the presence of multiple strains of $D$. nodosus on a single hoof. The finding of multiple strain infections on the same hoof is supported by other research. Gradin et al. (1993) reported the presence of one or two serotypes of 
D. nodosus on individual sheep/goat hooves. In the survey of Claxton et al. (1983), up to 4 serogroups per hoof were isolated from 38 out of 292 sheep and he also suggested that the more colonies that were examined per foot, the larger the number of serogroups that were detected. Moore et al. (2005) has reported that mixed serogroup infections are occur in both flocks and on individual feet.

\section{CONCLUSION}

Samples taken from the same farm and same sheep but different feet were found to contain different D. nodosus strains. This implies that the virulence of a $D$. nodosus strain varies for individual sheep or that the interaction between the host, pathogen and environment is complex. If this is the case then previous attempts to determine and classify the virulence of $D$. nodosus strains by both in vitro and in vivo investigations have possibly over-simplified the complexity of footrot as a disease.

\section{ACKNOWLEDGEMENTS}

This research was supported by Lincoln University Post Graduate Student Fund (LIN801) and Meat NZ (LU165).

\section{REFERENCES}

Bassam, B.J., G. Caetano-Anolles and P.M. Gresshoff, 1991. Fast and sensitive silver staining of DNA in polyacrylamide gels. Anal. Biochem., 196: 80-83.

Cagatay, I.T. and J.G.H. Hickford, 2005. Update on ovine footrot in New Zealand: Isolation, identification and characterization of Dichelobacter nodosus trains. Vet Microbiol., 111: 171-180.

Cagatay, I.T. and J.G.H. Hickford, 2006. Characterization of footrot bacteria Dichelobacter nodosus using per amplification and DNA sequence analysis. Turk. J. Vet. Anim. Sci., 30: 53-59.

Chetwin, D.H., L.C. Whitehead and S.E. Thorley, 1991. The recognition and prevalence of Bacteroides nodosus serotype $\mathrm{M}$ in Australia and New Zealand. Aust. Vet. J., 68: 154-155.

Claxton, P.D., L.A. Rýbeýro and J.R. Egerton, 1983. Classification of Bacteroides nodosus by agglutination tests. Aust. Vet. J., 60: 331-334.

Depiazzi, L.J., R.B. Richards, J. Henderson, J.I. Rood, M. Palmer and W.J. Penhale, 1991. Characterisation of virulent and benign strains of Bacteroides nodosus. Vet. Microbiol., 26: 151-160.
Dhungyel, O.P., R.J. Whittington and J.R. Egerton, 2002. Serogroup specific single and multiplex PCR with preenrichment culture and immuno-magnetic bead capture for identifying strains of $D$. nodosus in sheep with footrot prior to vaccination. Mol. Cell Probes., 16: 285-296.

Ghimire, S.C., J.R. Egerton, O.P. Dhungyel and H.D. Joshi, 1998. Identification and characterisation of serogroup $M$ among Nepalese isolates of Dichelobacter nodosus, the transmitting agent of footrot in small ruminants. Vet. Microbiol., 62: 217-233.

Gradin, J.L., A.E. Sonn and L. Petrovska, 1993. Serogrouping of Bacteroides nodosus isolates from 62 sources in the United States. Am. J. Vet. Res., 54: 1069-1073.

Gurung, R.B., O.P. Dhungyel, P. Tshering and J.R. Egerton, 2006. The use of an autogenous Dichelobacter nodosus vaccine to eliminate clinical signs of virulent footrot in a sheep flock in Bhutan. Vet. J., 172: 356-363.

Hindmarsh, F. and J. Fraser, 1985. Serogroups of Bacteroides nodosus isolated from ovine footrot in Britain. Vet. Rec., 116: 187-188.

John, G.H., R. Smith, K.J. Abraham and R.P. Ellis, 1999. Identification and grouping of Dichelobacter nodosus, using PCR and sequence analysis. Mol. CelL Probes., 13: 61-65.

Kingsley, D.F., F.H. Hindmarsh, D.M. Liardet and D.H. Chetwin, 1986. Distribution of Serogroups of Bacteroides nodosus with Particular Reference to New Zealand and the United Kingdom. In: Footrot in Ruminants, Stewart, D.J., J.E. Peterson, N.M. McKern and D.L. Emery (Eds.). Commonwealth Scientific and Industrial Research Organization, Melbourne.

Links, I.J. and S. Morris, 1996. Assessment of gelatin gel and elastase tests for detection of protease activity of Dichelobacter nodosus isolates from ovine footrot. Vet. Microbiol., 51: 305-318.

Moore, L.J., G.J. Wassink, L.E. Green and R. GrogonoThomas, 2005. The detection and characterisation of Dichelobacter nodosus from cases of ovine footrot in England and Wales. Vet. Microbiol., 108: 57-67.

Myers, G.S.A., D. Parker, K. Al-Hasani, R.M. Kennan and T. Seemann et al., 2007. Genome sequence and identification of candidate vaccine antigens from the animal pathogen Dichelobacter nodosus. Nat. Biotech., 25: 569-575.

Palmer, M.A., 1993. A gelatin test to detect activity and stability of proteases produced by Dichelobacter (bacteroides) nodosus. Vet. Microbiol., 36: 113-122.

Skerman, T.M., 1989. Isolation and Identification of Bacteroides nodosus. In: Footrot and Foot Abscess of Ruminants, Egerton, J.R., W.K. Yong and G.G. Riffkin (Eds.). CRC Press, Boca Raton, pp: 85-104. 
Stewart, D.J., 1989. Footrot in Sheep. In: Footrot and Foot Abscess of Ruminants, Egerton, J.R., W.K. Yong and G.G. Riffkin (Eds.). CRC Press, Boca Raton, Florida, pp: 5-45.

Stewart, D.J., J.E. Peterson, J.A. Vaughan, B.L. Clark, D.L. Emery, J.B. Caldwell and A.A. Kortt, 1986. The pathogenicity and cultural characteristics of virulent, intermediate and benign strains of Bacteroides nodosus causing ovine foot-rot. Aust. Vet. J., 63: 317-326.

Thorley, C.M. and S.E.J. Day, 1986. Serotyping Survey of 1296 Strains of Bacteroides nodosus Isolated from Sheep and Cattle in Great Bratain and Western Europe. In: Footrot in Ruminants, Stewart, D.J., J.E. Peterson, N.M. McKern and D.L. Emery (Eds.). CSIRO, Australia, pp: 135-142.
Wani, S.A., I. Samanta and S. Kawoosa, 2007. Isolation and characterization of Dichelobacter nodosus from ovine and caprine footrot in Kashmir, India. Res. Vet. Sci., 83: 141-144.

Whittington, R.J., V.F. Saunders and E.K. Moses, 1997. Antigens for serological diagnosis of ovine footrot. Vet. Microbiol., 54: 255-274.

Zakaria, Z., S. Radu, A.R. Sheikh-Omar, A.R. Mutalib, P.G. Joseph and G. Rusul, 1998. Molecular analysis of Dichelobacter nodosus isolated from footrot in sheep in Malaysia. Vet. Microbiol., 62: 243-250.

Zhou, H., S. Lottner, M. Ganter and J.G.H. Hickford, 2010. Identification of two new Dichelobacter nodosus strains in Germany. Vet. J., 184: 115-117. 